\title{
Generation of an osteoblast-based artificial niche that supports in vitro B lymphopoiesis
}

\author{
Jiyeon $\mathrm{Yu}^{1,3}$, Seunga Choi ${ }^{1,3}$, Hyeonkyeong Kim ${ }^{1}$, Nari Lee ${ }^{1}$, Hyeongseok Yun ${ }^{1}$, Sumi Kim ${ }^{1}$, Seong-Tae Jeong ${ }^{2}$
} and Jaerang Rho ${ }^{1}$

\begin{abstract}
B lymphocytes are produced from hematopoietic stem cells (HSCs) through the highly ordered process of B lymphopoiesis, which is regulated by a complex network of cytokines, chemokines and cell adhesion molecules derived from the hematopoietic niche. Primary osteoblasts function as an osteoblastic niche (OBN) that supports in vitro B lymphopoiesis. However, there are significant limitations to the use of primary osteoblasts, including their relative scarcity and the consistency and efficiency of the limited purification and proliferation of these cells. Thus, development of a stable osteoblast cell line that can function as a biomimetic or artificial OBN is necessary. In this study, we developed a stable osteoblastic cell line, designated OBN4, which functions as an osteoblast-based artificial niche that supports in vitro $\mathrm{B}$ lymphopoiesis. We demonstrated that the production of a $\mathrm{B}^{220^{+}}$cell population from Lineage ${ }^{-}\left(\mathrm{Lin}^{-}\right) \mathrm{Sca}_{-} \mathbf{1}^{+} \mathrm{c}-\mathrm{Kit}^{+}$hematopoietic stem and progenitor cells (HSPCs) was increased $\sim 1.7$-fold by OBN4 cells relative to production by primary osteoblasts and OP9 cells in coculture experiments. Consistently, OBN4 cells exhibited the highest production of ${\mathrm{B} 220^{+}} \mathrm{IgM}^{+}$cell populations $(6.7 \pm 0.6-13.6 \pm 0.6 \%)$ in an IL-7- and stromal cell-derived factor 1-dependent manner, with higher production than primary osteoblasts $(3.7 \pm 0.5-6.4 \pm 0.6 \%)$ and OP9 cells $(1.8 \pm 0.6-3.9 \pm 0.5 \%)$. In addition, the production of $\mathrm{B}_{2} 2 \mathrm{O}^{+} \mathrm{IgM}^{+} \mathrm{IgD}+$ cell populations was significantly enhanced by OBN4 cells $(15.4 \pm 1.1-18.9 \pm 3.2 \%)$ relative to production by primary osteoblasts $(9.5 \pm 0.6-14.6 \pm 1.6 \%)$ and OP9 cells $(9.1 \pm 0.5-$ $10.3 \pm 1.8 \%$ ). We conclude that OBN4 cells support in vitro B lymphopoiesis of $\mathrm{Lin}^{-} \mathrm{Sca}-1^{+} \mathrm{c}-\mathrm{Kit}^{+} \mathrm{HSPC}$ more efficiently than primary osteoblasts or OP9 stromal cells.
\end{abstract}

Experimental \& Molecular Medicine (2017) 49, e400; doi:10.1038/emm.2017.189; published online 24 November 2017

\section{INTRODUCTION}

Hematopoietic stem cells (HSCs), which are capable of selfrenewal, are pluripotent stem cells that can give rise to all types of blood cells through cellular differentiation and hematopoiesis. ${ }^{1}$ Hematopoiesis primarily occurs in the marrow or medullary cavities of the bones, which provide a hematopoietic inductive microenvironment known as the hematopoietic niche. ${ }^{1}$ The hematopoietic niche is composed of a specialized cell population of the bone marrow stroma, including fibroblasts, adipocytes, reticular cells, endothelial cells and osteoblasts. ${ }^{2,3}$ As the concept of a hematopoietic niche was first proposed by Schofield ${ }^{4}$ many efforts have been made to better understand the functional complexity and structural organization of the hematopoietic niche. ${ }^{3,5}$

B lymphopoiesis is a highly ordered process that results in the production of a functional B-cell population in bone marrow. ${ }^{6,7}$ The commitment to the B-cell lineage in $\mathrm{B}$ lymphopoiesis is characterized by the expression of distinct sets of surface markers, such as B220/CD45R, CD19, the Ig heavy chain, the Ig surrogate light chain and/or the Ig light chain, at discrete differentiation stages, including pre-pro-B, pro-B, pre-B and immature/naive B-cells. ${ }^{6}$ Recent studies have indicated that the cellular and molecular networks between HSCs and their hematopoietic niche play a prominent role in B lymphopoiesis. ${ }^{2,3,8}$ In particular, B lymphopoiesis is tightly regulated by a complex and dynamic network of cytokines, chemokines and cell adhesion molecules between HSCs and the hematopoietic niche. ${ }^{7}$ The contribution of bone marrow stromal cells expressing stromal cell-derived factor 1 (SDF-1/ CXCL12) or IL-7 to B lymphopoiesis was first proposed by Tokoyoda et al. ${ }^{9}$ In addition, studies have shown that OP9 stromal cells are able to support in vitro B lymphopoiesis without exogenous cytokine supplementation. ${ }^{10,11} \mathrm{OP} 9$ stromal cells also support in vitro B lymphopoiesis from embryonic

\footnotetext{
${ }^{1}$ Department of Microbiology and Molecular Biology, College of Bioscience and Biotechnology, Chungnam National University, Daejeon, Korea and ${ }^{2}$ Agency for Defense Development, Daejeon, Korea

${ }^{3}$ These authors contributed equally to this work.

Correspondence: Professor J Rho, Department of Microbiology and Molecular Biology, College of Bioscience and Biotechnology, Chungnam National University, 220 Gung-dong, Yuseong-gu, Daejeon 305-764, Korea.

E-mail: jrrho@cnu.ac.kr
}

Received 10 October 2016; revised 27 April 2017; accepted 28 May 2017 
a

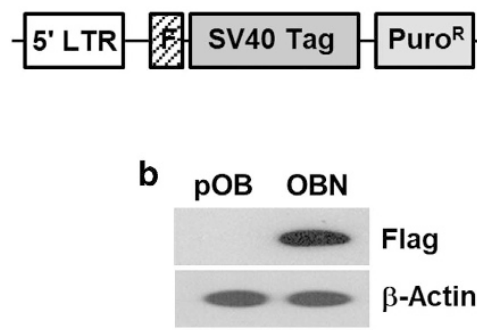

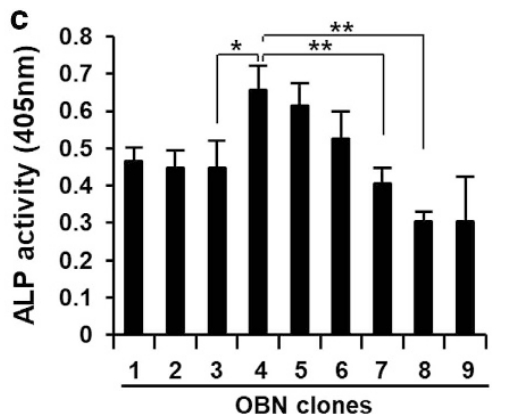

Figure 1 Development of the OBN4 clone. (a) Schematic diagram of the SV40 Tag expression plasmid. FLAG-epitope (hatched box); LTR, retroviral long terminal repeat; Puro ${ }^{\mathrm{R}}$, puromycin resistant cassette. (b) Expression of FLAG-tagged SV40 Tag in OBN cells. The expression of SV40 Tag was analyzed by western blotting with an anti-FLAG antibody. $\beta$-Actin was used as a loading control. pOB, primary osteoblast. (c) Comparison of ALP activities in OBN clones. The ALP activity levels of single OBN clones were analyzed through stimulation with $50 \mu \mathrm{m}$ ascorbic acid, $10 \mathrm{~mm} \beta$-glycerophosphate and $10^{-7} \mathrm{~m}$ dexamethasone for $6 \mathrm{~d}$. ${ }^{*} P<0.05$. ${ }^{*} P<0.01$.

stem cells and induced pluripotent stem cells, although the efficiency of $\mathrm{IgM}^{+}$B-cell production is quite low. ${ }^{12,13}$ In addition, studies have reported that murine primary osteoblasts are more capable of supporting the production of all stages of B-cell populations, including $\operatorname{IgM}^{+}$B lymphocytes, from HSCs in vitro. ${ }^{14}$ Thus, it is believed that primary osteoblasts are specialized cells that function as an osteoblastic niche (OBN) that supports in vitro B lymphopoiesis. ${ }^{14,15}$ However, there are limitations to the use of primary osteoblasts as an OBN for in vitro B lymphopoiesis. The major limitations include the relative difficulty of harvesting pure cells and the poor consistency and efficiency in achieving only limited proliferation. Thus, development of a stable osteoblast derivative cell line that functions as a biomimetic or artificial OBN to efficiently induce in vitro B lymphopoiesis is necessary.

In this study, we developed an osteoblast-based artificial niche to overcome the limited availability of primary osteoblasts for in vitro B lymphopoiesis. To generate stable osteoblast cell lines that function as an $\mathrm{OBN}$, we immortalized primary osteoblasts via transduction with a retrovirus harboring the SV40 large T antigen (SV40 Tag). We established one stable clone, designated OBN4, that exhibited higher expression of osteoblast markers than the other stable clones. We determined that the production of a B-cell population from HSPCs was more efficiently induced by OBN4 cells than primary osteoblasts or OP9 stromal cells. Thus, we have developed a new osteoblast-based artificial niche that supports in vitro B lymphopoiesis.

\section{MATERIALS AND METHODS}

Chemicals, antibodies, cell lines and plasmids

Recombinant rat parathyroid hormone (PTH) was purchased from Merck-Millipore (Bedford, MA, USA). Recombinant human bone morphogenic protein-2 (BMP-2), mouse stem cell factor (SCF), mouse Flt3 ligand (Flt3L), mouse IL-4, mouse IL-7, mouse SDF-1, mouse CD40L and mouse thrombopoietin (TPO) were purchased from PeproTech (Rocky Hill, NJ, USA). Chemicals were purchased from Sigma-Aldrich (St Louis, MO, USA). An HSC isolation kit was purchased from Miltenyi Biotec (Auburn, CA, USA). Specific antibodies were purchased from the following commercial sources: antiFLAG and anti- $\beta$-actin from Sigma-Aldrich; anti-B220, anti-Sca-1, anti-lineage cells (anti-Lin), anti-IgD and anti-IgM from BD Biosciences (San Jose, CA, USA); anti-Ki67, anti-Flk2, anti-CD2, antiCD19, anti-CD23, anti-CD34, anti-CD43 and anti-CD93 from eBioscience (San Diego, CA, USA); and anti-receptor activator of nuclear factor $\kappa B$ ligand (RANKL) from Novus (Littleton, CO, USA). PlatE (retroviral packaging cell line), OP9 (murine stromal cell line), mouse embryonic fibroblast (MEF) and primary osteoblast cells were prepared and maintained as described previously. ${ }^{16,17}$ The animal study was approved (No. CNU-00132) by the Animal Experiment Ethics Committee of Chungnam National University. To construct the retroviral SV40 Tag expression plasmid (Figure 1a), SV40 Tag was subcloned into the retroviral vector pMX-puro-FLAG ${ }^{17}$ through PCR amplification. The following primers were used for plasmid construction: SV40 Tag (sense), 5'-CCC GGA TCC ACC ATG GAT AAA GTT TTA AAC AGA-3', and SV40 Tag (antisense), 5'-CCC GAA TTC TTA TGT TTC AGG TTC AGG GGG AGG-3'. The expression of SV40 Tag was analyzed via western blotting with an anti-FLAG antibody, as described previously. ${ }^{18}$

\section{Generation of the OBN4 clone}

Primary osteoblasts were isolated from the calvaria of newborn mice through collagenase and dispase digestion as described previously. ${ }^{17}$ Briefly, calvaria were treated with collagenase $\left(10 \mathrm{mg} \mathrm{m}^{-1}\right)$ and dispase $\left(20 \mathrm{mg} \mathrm{ml}^{-1}\right)$ at $37^{\circ} \mathrm{C}$ for $10 \mathrm{~min}$ in three cycles. The collected cells were differentiated into primary osteoblasts by culture in $\alpha$-MEM including 10\% FBS and supplemented with $50 \mu \mathrm{M}$ ascorbic acid, $10 \mathrm{~mm} \beta$-glycerophosphate, $100 \mathrm{ng} \mathrm{ml}^{-1} \mathrm{BMP}-2$ and $10^{-7} \mathrm{M}$ dexamethasone for $5 \mathrm{~d}$. The primary osteoblasts were further activated by treatment with $50 \mu \mathrm{M}$ ascorbic acid, $10 \mathrm{~mm} \beta$-glycerophosphate and $10^{-7}$ м PTH for $3 \mathrm{~d}$. To prepare a retroviral supernatant harboring the SV40 Tag expression cassette, PlatE cells were transfected with retroviral SV40 Tag expression plasmid DNA using the TurboFect transfection reagent (Fermentas, Hanover, MD) according to the manufacturer's instructions. Subsequently, the PTH-stimulated primary osteoblasts were infected with the retroviral supernatant harboring the SV40 Tag expression cassette with polybrene $\left(8 \mu \mathrm{g} \mathrm{ml}^{-1}\right)$ for $6 \mathrm{~h}$. The retrovirally transduced cells were selected with puromycin $\left(2 \mu \mathrm{g} \mathrm{ml}^{-1}\right)$ for $14 \mathrm{~d}$ to generate a stable cell line. The puromycin-resistant cells were then cultured in 96-well plates via serial dilution to isolate a single osteoblast cell line. From the serial dilution culture, nine single cell lines, referred to as OBN clones, were isolated. Subsequently, alkaline phosphatase (ALP) activity was analyzed in the nine OBN clones, as described previously. ${ }^{17}$ Finally, the OBN4 clone 
exhibiting the highest activity in the ALP assay was chosen as the osteoblast-based artificial niche.

\section{Characterization of the OBN4 clone}

Osteoblast differentiation and function were analyzed through the ALP assay, alizarin red staining (ARS) and the tartrate-resistant acid phosphatase (TRAP) assay, as described previously. ${ }^{17,19}$ The expression of osteoblast markers and cytokines was analyzed via real-time PCR, as described previously. ${ }^{19}$ Cell proliferation was analyzed with the Cell Counting Kit-8 (CCK-8, Dojindo Laboratories, Kumamoto, Japan) according to the manufacturer's instructions. Cell surface expression of osteoblast markers was analyzed through flow cytometry with antibodies against Sca-1 and RANKL, as described previously. ${ }^{19}$ The cell cycle was analyzed via propidium iodide staining as described previously. ${ }^{20}$ Real-time PCR was performed as described previously. ${ }^{18}$ The primers used for real-time PCR amplification were as follows: osteocalcin (sense), 5'-TTA CTT TAT GCT TCT CAG AGC-3'; osteocalcin (antisense), 5'-AAA TAG TGA TAC CGT AGA TGC-3'; osteopontin (sense), 5'-TGC ACC CAG ATC CTA TAG CCA-3'; osteopontin (antisense), 5'-TGT GGT CAT GGC TTT CAT TGG-3'; SDF-1 (sense), 5'-AAA CCA GTC AGC CTG AGC TAC-3'; SDF-1 (antisense), 5'-GTT TAA AGC TTT CTC CAG GTA-3'; IL-7 (sense), 5'-TGC CAC ATT AAA GAC AAA GAA-3'; IL-7 (antisense), 5'-ACT GCC CTT CAA AAT TTT ATT-3'; vascular cell adhesion protein-1 (VCAM-1, sense), 5'-GTT CCA GCG AGG GTC TAC C-3'; VCAM-1 (antisense), 5'-AAC TCT TGG CAA ACA TTA GGT GT-3'; IL-4 (sense), 5'-AGA TGG ATG TGC CAA ACG TCC TCA-3'; IL-4 (antisense), 5'-AAT ATG CGA AGC ACC TTG GAA GCC- 3'; B-cell activating factor (BAFF, sense), 5'-ACG GAG ACG ACA CCT TCT TT-3'; BAFF (antisense), 5'-GGC TTT CCC CAT CTT TTA GTT-3'. Actin expression served as an internal control. ELISA was performed, as described previously. ${ }^{18}$ Briefly, the culture supernatants were harvested, and cytokine levels were measured at $450 \mathrm{~nm}$ using an ELISA Reader (Bio-Rad) with an IL-7 ELISA Kit (R\&D Systems, MN, USA) or an SDF-1 ELISA Kit (R\&D Systems) according to the manufacturers' instructions.

\section{In vitro expansion and isolation of HSPCs}

HSPCs derived from the bone marrow of 8-week-old male C57BL/6J mice were expanded in vitro in IMDM containing 10\% FBS and supplemented with FLT3L $\left(100 \mathrm{ng} \mathrm{ml}^{-1}\right)$, TPO $\left(100 \mathrm{ng} \mathrm{ml}^{-1}\right)$ and SCF $\left(100 \mathrm{ng} \mathrm{ml}^{-1}\right.$ ) over $27 \mathrm{~d}$ of culture as described previously. ${ }^{21-23} \mathrm{Lin}^{-}$ $\mathrm{Sca}^{-}{ }^{+} \mathrm{c}-\mathrm{Kit}^{+}$(LSK) HSPCs were isolated from the expanded cell population using an HSC isolation kit (Miltenyi Biotec) according to the manufacturer's instructions. The purified cells were analyzed via flow cytometry with antibodies against B220, Sca-1, Lin, c-Kit, Flk2, CD2, CD34, CD43, CD93 and IgM, as described previously. ${ }^{14,19}$

\section{In vitro $\mathrm{B}$ lymphopoiesis}

In vitro $\mathrm{B}$ lymphopoiesis was performed as described previously, ${ }^{14}$ with slight modification. Briefly, primary osteoblasts, OP9 stromal cells, MEFs, mitomycin $\left(1.5 \mu \mathrm{g} \mathrm{ml}^{-1}\right)$-treated OBN4 $\left(\mathrm{OBN} 4^{\mathrm{MT}}\right)$ and OBN4 cells were cultured in $\alpha$-MEM including 10\% FBS and supplemented with $50 \mu \mathrm{M}$ ascorbic acid, $10 \mathrm{~mm} \beta$-glycerophosphate, $100 \mathrm{ng} \mathrm{ml}^{-1}$ BMP-2 and $10^{-7} \mathrm{M}$ dexamethasone for $5 \mathrm{~d}$. Subsequently, the cultured cells were further stimulated by treatment with $50 \mu \mathrm{M}$ ascorbic acid, $10 \mathrm{~mm} \beta$-glycerophosphate and $10^{-7} \mathrm{M}$ PTH for $3 \mathrm{~d}$. The stimulated cells were seeded at $6 \times 10^{4}$ cells per well in 6-well plates. After $1 \mathrm{~d}$ of culture, the cells were cocultured with purified $\mathrm{Lin}^{-} \mathrm{Sca}^{+}{ }^{+} \mathrm{c}-\mathrm{Kit}^{+}$HSPCs $\left(10^{5}\right.$ cells per well $)$ in $\alpha$-MEM supplemented with $10 \%$ FBS, $50 \mu \mathrm{m}$ ascorbic acid, $10 \mathrm{~mm} \beta$-glycerophosphate and $10^{-7} \mathrm{M}$ PTH in the presence or absence of IL-7 $\left(100 \mathrm{ng} \mathrm{ml}^{-1}\right)$ and SDF-1 $\left(100 \mathrm{ng} \mathrm{ml}^{-1}\right)$ for $7 \mathrm{~d}$ to induce in vitro $\mathrm{B}$ lymphopoiesis. The differentiated B-cell populations were collected through treatment with $1 \mathrm{mg} \mathrm{ml}^{-1}$ collagenase $\mathrm{P}$ and $0.25 \%$ trypsin and analyzed via flow cytometry with antibodies against B220, CD23, CD93, IgD and IgM. To examine the activation of B-cell populations produced by cocultures, B220 cells seeded at $3 \times 10^{5}$ cells per well in a 6-well plate were stimulated for $24 \mathrm{~h}$ with lipopolysaccharide (LPS, $\left.1 \mu \mathrm{g} \mathrm{ml}^{-1}\right)$, IL-4 $\left(10 \mathrm{ng} \mathrm{ml}^{-1}\right)$ and CD40L $\left(100 \mathrm{ng} \mathrm{ml}^{-1}\right)$ treatment in RPMI media supplemented with $10 \%$ FBS, $2 \mathrm{~mm}$ glutamine, $1 \mathrm{~mm}$ sodium pyruvate and $50 \mu \mathrm{m} \quad \beta$-mercaptoethanol, as described previously. ${ }^{24}$ Purified $\mathrm{B} 220^{+}$splenocytes $\left(3 \times 10^{5}\right.$ cells per well) with anti-B220-conjugated magnetic beads (Miltenyi Biotec) were used as a positive control. After $24 \mathrm{~h}$ of stimulation, the numbers of colonized cells were counted, and gene expression levels for the markers of B-cell activation were analyzed by real-time PCR. The primers used for realtime PCR amplification were as follows: interferon regulatory factor 4 (IRF4, sense), 5'-GGT GTA CAG GAT TGT TCC AGA GG-3'; IRF4 (antisense), 5'-GCA GAG AGC CAT AAG GTG CTG-3'; H2-IA $\beta$ (sense), 5'- ACC CAG CCA AGA TCA AAG TGC-3'; H2-IA $\beta$ (antisense), 5'-TGC TCC ACG TGA CAG GTG TAG A-3'; X-box binding protein 1 (XBP1, sense), 5'-GGA GCA GCA AGT GGT GGA TT-3'; XBP1 (antisense), 5'-CAG CGT GTC CAT TCC CA AG-3'.

\section{Statistical analysis}

All experiments were performed at least three times. The presented data represent the means \pm s.d. ( $n=3$ per group). Student's $t$-test was used to determine the significance of the differences between the experimental samples.

\section{RESULTS}

\section{Generation of the OBN4 stable cell line}

To generate a stable osteoblast cell line functioning as an OBN that supports in vitro B lymphopoiesis, we isolated mesenchymal stem cells from the calvaria of newborn mice. The isolated mesenchymal stem cells were differentiated into primary osteoblasts by treatment with BMP-2 $\left(100 \mathrm{ng} \mathrm{ml}^{-1}\right)$ and dexamethasone $\left(10^{-7} \mathrm{M}\right)$ for $5 \mathrm{~d}$. The primary osteoblasts were further activated by treatment with PTH $\left(10^{-7} \mathrm{M}\right)$ for $3 \mathrm{~d}$. The PTH-stimulated primary osteoblasts were transduced with retroviral supernatants harboring a FLAG-tagged SV40 Tag expression cassette (Figure 1a) and were selected via puromycin treatment. Puromycin-resistant cells were further cultured through at least 30 passages to establish a stable cell line, and the expression of SV40 Tag in stable cells was identified by antiFLAG western blotting analysis (Figure 1b). We then isolated nine single-cell clones, referred to as OBN clones, via serial dilution culture and examined the ALP activities of the nine OBN clones (Figure 1c). The OBN4 clone exhibited the highest ALP activity $(0.66 \pm 0.06)$ among the tested OBN clones and was chosen for further analyses. Subsequently, we examined the osteoblast characteristics of the OBN4 clone. Compared with primary osteoblasts, OBN4 cells exhibited 2.5-fold higher ALP activity (Figure 2a). Similarly, mineralization measured via ARS was increased 1.9-fold in OBN4 cells (Figure 2b). The expression of bone formation markers, such as osteocalcin and osteopontin, was also increased ( $\geqslant 5.5$-fold) in OBN4 cells relative 
a
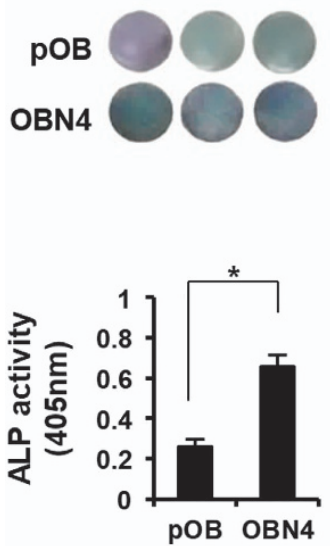

d
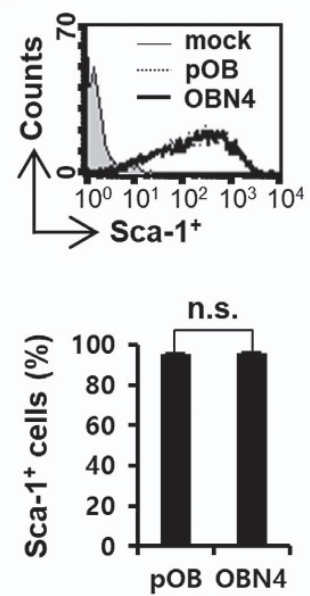

b
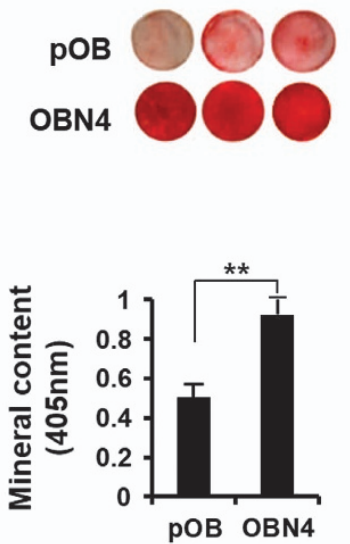

e
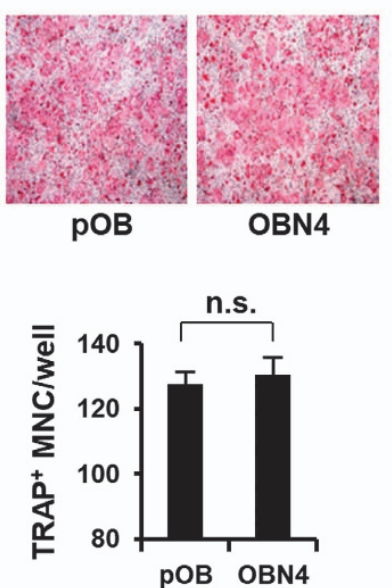

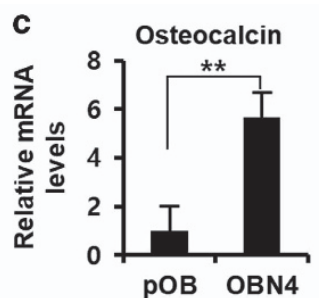

Osteopontin

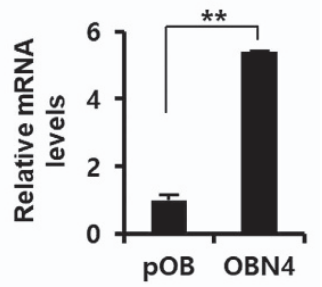

f
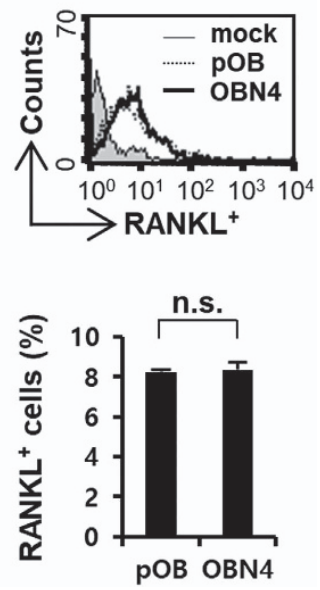

Figure 2 Osteoblastic characteristics of the OBN4 clone. (a) ALP activity of the OBN4 clone. ALP activities were analyzed between OBN4 and primary osteoblast (pOB) cells via stimulation with $50 \mu \mathrm{m}$ ascorbic acid, $10 \mathrm{~mm} \beta$-glycerophosphate and $10^{-7} \mathrm{M}$ dexamethasone for $6 \mathrm{~d}$. Photographs of ALP-positive cells in triplicate samples are presented (top panel), and ALP activities were quantified (bottom panel). (b) Mineralization of the OBN4 clone. The mineralization of cultured cells with $50 \mu \mathrm{m}$ ascorbic acid and $10 \mathrm{~mm} \beta$-glycerophosphate for 21 d was measured using ARS staining. ARS-positive cells in triplicate samples were photographed (top panel), and ARS activities were quantified (bottom panel). (c) Expression of osteoblast markers in the OBN4 clone. The expression levels of osteocalcin (top panel) and osteopontin (bottom panel) were analyzed via real-time PCR analysis. (d) Expression of the Sca-1 lineage marker in the OBN4 clone. The expression of Sca-1 antigen was analyzed via flow cytometry with an anti-Sca- 1 antibody (top panel). The percentages of the Sca- $1^{+}$cell population are summarized in the bottom panel. Mock, non-stained cells. (e) Comparison of the ability to support osteoclast differentiation in coculture assays. Cells were cocultured with bone marrow-derived HSCs in the presence of vitamin D3 and prostaglandin E2 for 6 d. Osteoclast formation was analyzed through TRAP staining (top panel). The number of TRAP-positive multinucleated osteoclasts (TRAP+ MNCs ( $\geqslant$ three nuclei)) was counted (bottom panel). (f) RANKL expression in the OBN4 clone. The surface expression of RANKL was analyzed via flow cytometry with an anti-RANKL antibody (top panel). The percentages of the RANKL ${ }^{+}$cell population are summarized in the bottom panel. NS, not significant. ${ }^{*} P<0.05$. ${ }^{*} P<0.01$.

to primary osteoblasts (Figure 2c). However, the surface level of the osteoblast lineage marker Sca-1 did not differ between OBN4 cells and primary osteoblasts (Figure 2d). In addition, the functional properties supporting osteoclast differentiation from HSCs under coculture with OBN4 were similar to the results obtained using primary osteoblasts (Figure 2e and f).

Next, we examined the cell proliferation of OBN4 cells using a CCK-8 assay kit. We observed significantly increased cell proliferation in OBN4 cells relative to that in primary osteoblasts (Figure 3a). Similarly, the expression of the cell proliferation marker Ki67 and the number of cells in G2-M phase transition were 2.4-fold and 3.4-fold higher, respectively, in OBN4 cells than in primary osteoblasts (Figure 3b and c). Notably, we also observed significantly enhanced expression of SDF-1 and IL-7 in OBN4 cells compared with the levels in primary osteoblasts and $\mathrm{OBN} 4^{\mathrm{MT}}$ cells placed in cell cycle arrest with low-level mitomycin C treatment (Figure 3d). Similarly, ELISA assays revealed enhanced levels of secreted SDF-1 and IL-7 in OBN4 cells (Figure 3e). In addition, we observed significantly enhanced expression of the B-cell maturation 
a

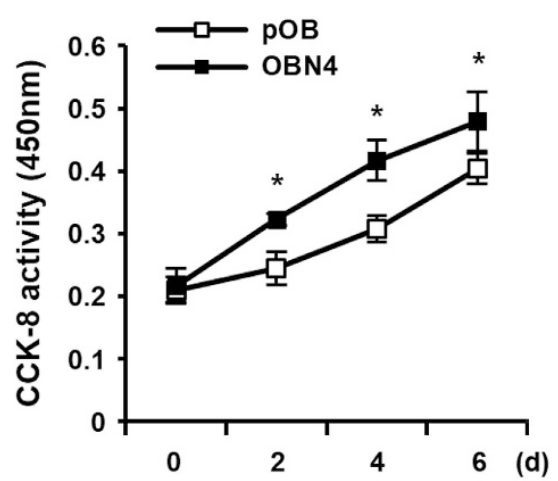

b
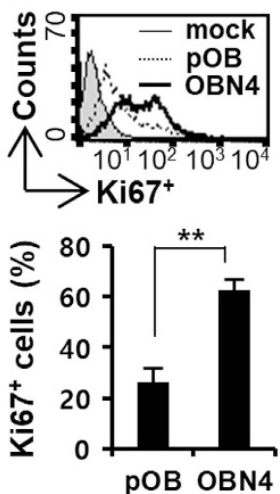

C

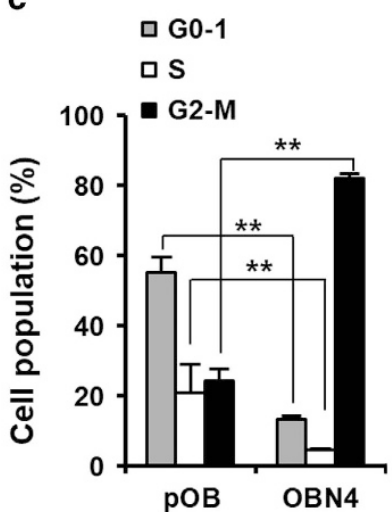

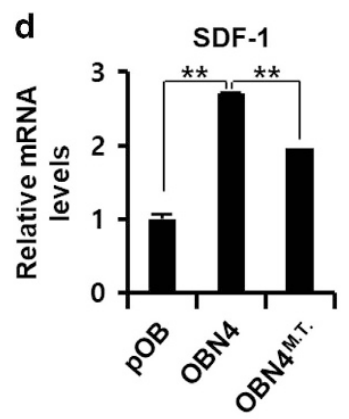

f

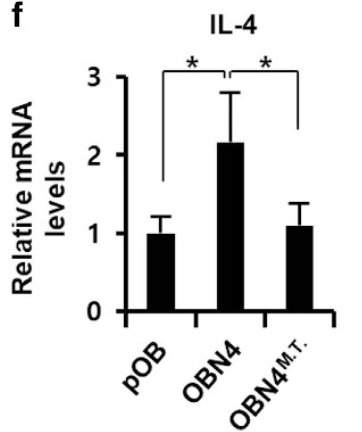

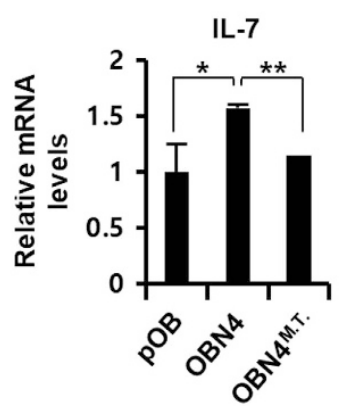

BAFF

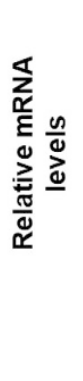

e

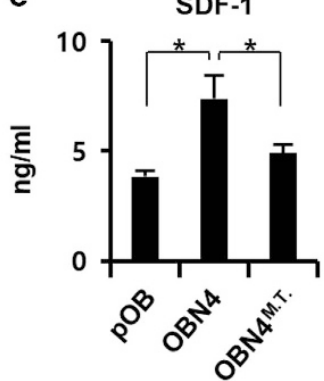

IL-7

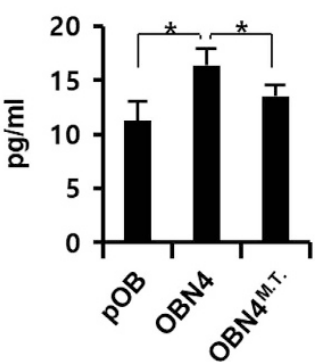


a In vitro expansion of HSPCs (Day 27)
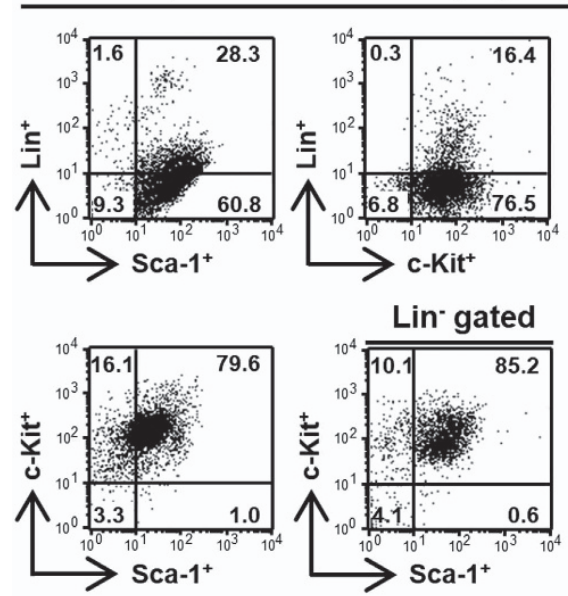

b
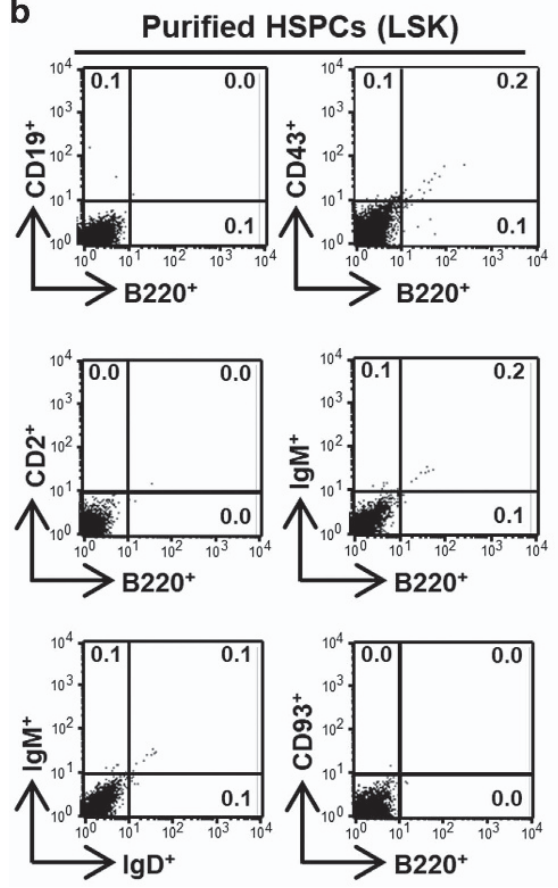

LSK purification $\rightarrow$
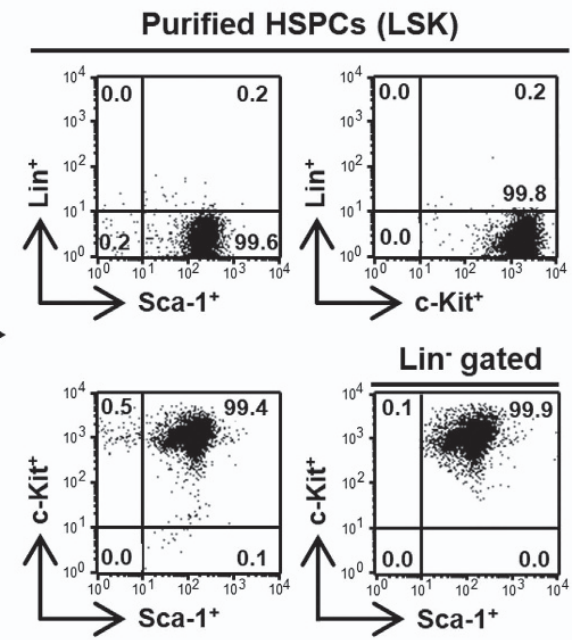

C
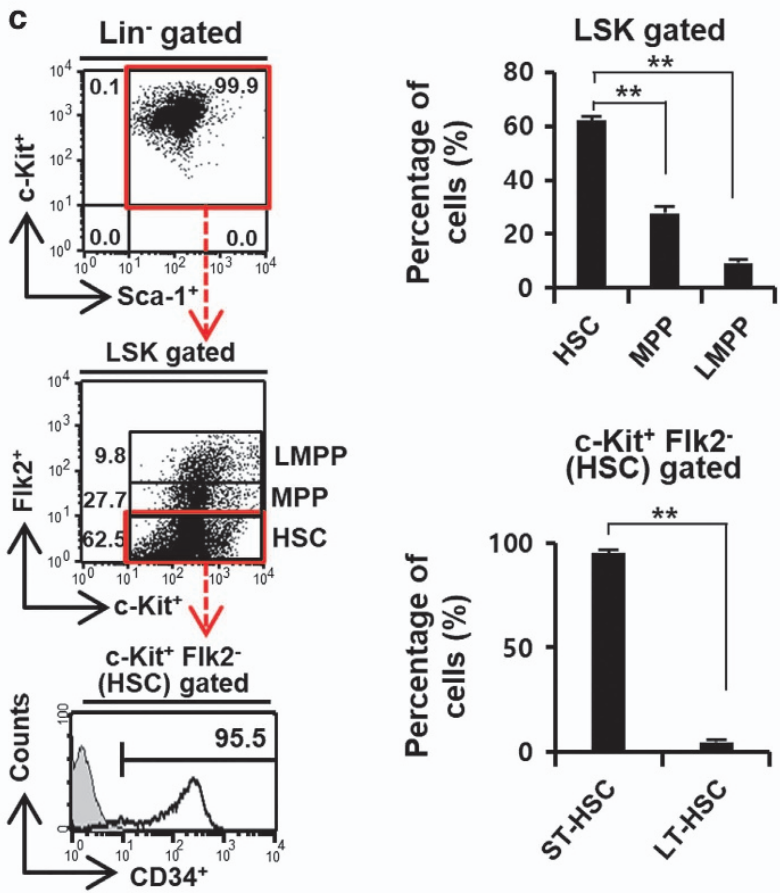

Figure 4 In vitro expansion and isolation of Lin ${ }^{-}$Sca- $1^{+}$c-Kit ${ }^{+}$HSPCs. (a) In vitro expansion of HSCs. Bone marrow-derived HSPCs were expanded by treatment with FLT3L $\left(100 \mathrm{ng} \mathrm{ml}^{-1}\right)$, TPO $\left(100 \mathrm{ng} \mathrm{ml}^{-1}\right)$ and SCF $\left(100 \mathrm{ng} \mathrm{m}^{-1}\right)$ for $27 \mathrm{~d}$. The expanded cell populations were analyzed via flow cytometry with anti-Lin, Sca-1 and c-Kit antibodies (left panel). Lin ${ }^{-}$Sca- $1^{+}$c-Kit ${ }^{+}$(LSK) cells were isolated from 27 d of expanded culture using an HSC isolation kit. The isolated LSK cells were analyzed via flow cytometry with anti-Lin, Sca-1 and c-Kit antibodies (right panel). (b) The contamination of isolated LSK cells by B-lineage cells. Isolated Lin ${ }^{-} \mathrm{Sca}^{-1^{+}} \mathrm{C}-\mathrm{Kit}{ }^{+} \mathrm{HSPCs}$ were analyzed via flow cytometry with anti-B220, CD19, CD43, CD2, IgM, IgD and CD93 antibodies. (c) Analysis of isolated Lin ${ }^{-}$Sca-1 ${ }^{+}$C-Kit ${ }^{+}$HSPCs. Lin $^{-}$gated cells (bolded box) were analyzed via flow cytometry with anti-Sca-1 and c-Kit antibodies (left top panel). For the analysis of the HSC, MPP and LMPP populations of HSPCs, the LSK cells were analyzed with anti-c-Kit and Flk2 antibodies (left middle panel). The averaged percentages of the HSC, MPP and LMPP populations among HSPCs were summarized (right top panel). The populations of LTHSC and ST-HSC in the HSC (c-Kit ${ }^{+}$Flk2-)-gated cells (bolded box) were further analyzed with anti-CD34 antibody (left bottom panel). The averaged percentages of LT-HSC and ST-HSC population in HSC-gated cells were summarized (right bottom panel). ** $P<0.01$.

$\mathrm{Lin}^{+}$-depleted and Sca- $1^{+} \mathrm{c}-\mathrm{Kit}^{+}$-selected cells using the HSC isolation kit, we obtained $4.1 \pm 0.1 \times 10^{6}$ of LSK cells with a purity of $99.6 \pm 0.3 \%$ (Figure $4 \mathrm{a}$ and Supplementary Table S1). Contamination of the isolated LSK cells with B lineage cells was observed only at background levels $(\leqslant 0.3 \%)$ (Figure $4 \mathrm{~b})$. It has been reported that LSK cells contain several multipotent populations, such as HSCs (including long-term HSCs (LTHSCs) and short-term HSCs (ST-HSCs)), multipotent progenitors (MPPs) and lymphoid-primed multipotent progenitors (LMPPs). ${ }^{25,26}$ Thus, we next analyzed HSPC subsets from the isolated LSK cells using the surface markers Flk2 and CD34. From double staining of the isolated LSK cells with anti-c-Kit 
and anti-Flk2, we observed a large portion $\left(2.6 \pm 0.1 \times 10^{6}\right.$ $(62.1 \pm 1.4 \%))$ of LSK cells designated LSK Flk2 ${ }^{-}$HSCs, and the remaining cells were LSK Flk2 ${ }^{\text {low }}$ MPPs $\left(1.1 \pm 0.1 \times 10^{6}\right.$ $(27.8 \pm 2.4 \%))$ and LSK Flk2 ${ }^{\text {high }}$ LMPPs $\left(0.4 \pm 0.1 \times 10^{6}\right.$ $(9.2 \pm 1.2 \%))$ (Figure $4 \mathrm{c}$ and Supplementary Table S1). When we stained LSK Flk2 ${ }^{-}$HSCs with anti-CD34 antibody, most of the cells were designated LSK Flk2 ${ }^{-} \mathrm{CD}_{4}{ }^{+}$ST-HSCs $(95.4 \pm 1.4 \%)$, while LSK Flk2 ${ }^{-}$CD34- LT-HSCs was observed only at a background level $(4.6 \pm 1.3 \%)$ (Figure $4 \mathrm{c}$ and Supplementary Table S1). Thus, we successfully obtained purified HSPCs, which may act as primary progenitor cells for in vitro B lymphopoiesis, through the in vitro expansion of murine HSCs.

\section{OBN4 cells efficiently support in vitro B lymphopoiesis in HSPCs}

To examine whether the OBN4 clone functions as an osteoblast-based artificial niche that supports in vitro $\mathrm{B}$ lymphopoiesis, purified HSPCs (LSK cells) were cocultured with OBN4 cells in the presence or absence of IL-7 and SDF-1. During $7 \mathrm{~d}$ of coculture, we observed a time-dependent increase in the number of non-adherent cells on OBN4 coculture plates (Figure 5a). Interestingly, the number of non-adherent cells in OBN4 coculture treated with IL-7 and SDF-1 was 1.3-1.5-fold higher than that of untreated OBN4 cells (Figure 5a). In agreement with these results, we observed a similar fold increase (1.6-1.7-fold) in the production of $\mathrm{B} 220^{+}$ cell population from the OBN4 coculture following supplementation with IL-7 and SDF-1 (Figure 5b). Next, we analyzed the cell population of non-adherent cells using flow cytometry with antibodies against B220, CD2, CD19, CD43, CD93, IgD and IgM to examine in vitro B lymphopoiesis. At $3 \mathrm{~d}$ of OBN4 coculture with IL-7 and SDF-1 treatment, we observed the generation of $\mathrm{B} 220^{+} \mathrm{CD}_{1} 9^{-} \mathrm{CD} 43^{+}$pre-pro-B-cells and $\mathrm{B} 220^{+}$ $\mathrm{CD}_{19}{ }^{+} \mathrm{CD} 3^{+}$pro-B-cells (Figure $5 \mathrm{c}$ ). These cell populations were time-dependently increased after $3 \mathrm{~d}$ of coculture (Figure $5 \mathrm{~d}$ ). After $5 \mathrm{~d}$ of coculture, we also observed a timedependent increase in the number of $\mathrm{B} 220^{+} \mathrm{CD} 19^{+} \mathrm{CD}^{-} 3^{-}$or $\mathrm{B}_{220}{ }^{+} \mathrm{CD}^{+} \mathrm{IgM}^{-}$pre-B-cells, $\mathrm{B} 220^{+} \mathrm{CD}^{+} \mathrm{IgM}^{+}$or $\mathrm{B} 220^{+}$ $\mathrm{IgM}^{+} \mathrm{IgD}^{-}$immature $\mathrm{B}$-cells and $\mathrm{B}_{220^{+}} \mathrm{IgM}^{+} \mathrm{IgD}^{+}$or $\mathrm{B} 220^{+}$ $\mathrm{IgD}^{+} \mathrm{CD}^{-}$mature B-cells (Figure $5 \mathrm{c}$ and $\mathrm{d}$ ). We obtained similar results for the production of B-cell populations in OBN4 cells alone without any cytokine supplement, although the fold increases in B-cell production were lower than that of IL-7/SDF-1-treated OBN4 cells (Figure 5d and Supplementary Figure S1). Data from the cell population identification of OBN4 cocultures were averaged and summarized in Supplementary Table S2.

Next, we compared the production of B-cell populations via in vitro B lymphopoiesis in cocultures of purified HSPCs with primary osteoblasts, OBN4, OBN4 ${ }^{\mathrm{MT}}$ or OP9 stromal cells in the presence or absence of IL-7 and SDF-1. To exclude the possibility of unexpected cell proliferation of contaminated $\mathrm{B} 220^{+}$cells derived from the purification steps, HSPCs were cocultured with MEF cells as a negative control. After $7 \mathrm{~d}$ of coculture, we first examined the increase in non-adherent cells in the coculture plates. We observed that the number of nonadherent cells was significantly increased in all coculture plates, except for the MEF plates (Supplementary Table S3). Among the tested cell types, OBN4 cells exhibited the largest increase $\left(6.88 \pm 0.3 \times 10^{5}\right.$ cells $)$ in the number of non-adherent cells relative to the initial number of LSK cells $\left(1 \times 10^{5}\right.$ cells $)$, and this increase occurred in an IL-7 and SDF-1-dependent manner $\left(9.23 \pm 1.1 \times 10^{5}\right.$ cells $)$. Similarly, we observed that the production of the $\mathrm{B} 220^{+}$population was significantly increased in OBN4 cells $\left(2.27 \pm 1.4 \times 10^{5}\right.$ cells $\left.(38.0 \pm 1.2 \%)\right)$ compared with the production in primary osteoblasts $\left(1.54 \pm 3.2 \times 10^{5}\right.$ cells $(29.5 \pm 9.3 \%)), \quad \mathrm{OBN} 4^{\mathrm{MT}} \quad\left(1.63 \pm 3.4 \times 10^{5} \quad\right.$ cells $(29.2 \pm 3.4 \%))$ and OP9 cells $\left(1.41 \pm 2.0 \times 10^{5}\right.$ cells $(29.6 \pm 1.8 \%))$ after $7 \mathrm{~d}$ of coculture, whereas B220 ${ }^{+}$cells were detected only at background levels $(\leqslant 0.4 \%)$ in MEFs (Figure $6 \mathrm{a}$ and c). In addition, the population of $\mathrm{B} 220^{+} \mathrm{IgM}^{+}$doublepositive cells, which can be considered immature B-cells, was significantly increased in cocultures with OBN4 $\left(4.6 \pm 0.5 \times 10^{4}\right.$ cells $(6.7 \pm 0.6 \%))$ compared with the population in primary osteoblasts $\left(1.9 \pm 0.4 \times 10^{4}\right.$ cells $\left.(3.7 \pm 0.5 \%)\right), \quad$ OBN4 ${ }^{\mathrm{MT}}$ $\left(3.1 \pm 0.6 \times 10^{4} \quad\right.$ cells $\left.(5.6 \pm 0.7 \%)\right)$ and OP9 cells $\left(1.8 \pm 0.6 \times 10^{4}\right.$ cells $(3.7 \pm 0.6 \%)$ ) (Figure $6 \mathrm{a}$ and $\left.\mathrm{c}\right)$. In agreement with these results, the combination of IL-7 and SDF-1 with OBN4 cocultures produced the largest increase in the production of ${\mathrm{B} 220^{+}}$cells $\left(3.76 \pm 0.2 \times 10^{5}\right.$ cells $(40.9 \pm 2.4 \%))$ or ${\mathrm{B} 220^{+}}^{\mathrm{IgM}^{+}}$cells $\left(1.25 \pm 0.1 \times 10^{5}\right.$ cells $(13.6 \pm 0.6 \%)$ ) (Figure $6 \mathrm{~b}$ and $\mathrm{c}$ ).

Interestingly, we observed similarly enhanced production of $\mathrm{B}_{220}{ }^{+} \mathrm{IgM}^{+} \mathrm{IgD}^{+}$cells in OBN4 coculture (Figure $6 \mathrm{~b}$ and $\mathrm{c}$ ). $\mathrm{B}_{22}{ }^{+} \mathrm{IgM}^{+} \mathrm{IgD}^{+}$cells can be further subdivided based on CD23 and CD93 expression into CD93 ${ }^{+}$CD23- (newly formed B-cells), $\mathrm{CD}^{+}{ }^{+} \mathrm{CD}_{23}{ }^{+}$(transitional B-cells) and $\mathrm{CD} 93^{-}$ $\mathrm{CD}^{+} 3^{+}$(mature B-cells). ${ }^{27-29}$ Thus, we further analyzed the population of $\mathrm{B}_{22} 20^{+} \mathrm{IgM}^{+} \mathrm{IgD}^{+}$cells with antibodies against CD23 and CD93. Notably, we found that the population of $\mathrm{CD}^{-}{ }^{-} \mathrm{CD} 23^{+}$mature B-cells was significantly increased in coculture with OBN4 cells $\left(6.0 \pm 0.7 \times 10^{4}\right.$ cells $\left.(70.4 \pm 4.4 \%)\right)$ relative to primary osteoblasts $\left(1.7 \pm 0.2 \times 10^{4}\right.$ cells $(53.2 \pm 1.8 \%)), \mathrm{OBN}^{\mathrm{MT}}\left(2.2 \pm 0.1 \times 10^{4}\right.$ cells $\left.(58.8 \pm 0.1 \%)\right)$ and OP9 $\left(1.5 \pm 0.1 \times 10^{4}\right.$ cells $\left.(53.2 \pm 1.8 \%)\right)$ upon treatment with IL-7 plus SDF-1 (Figure $6 \mathrm{~b}$ and $\mathrm{c}$ ). In addition, OBN4 cells exhibited the highest production of the $\mathrm{CD}^{3} 3^{+} \mathrm{CD} 23^{+}$ transitional B-cell population $\left(0.7 \pm 0.1 \times 10^{4}\right.$ cells $(\mathrm{PBS})$ or $1.1 \pm 0.3 \times 10^{4}$ cells (IL-7 and SDF-1)), but the numbers of $\mathrm{CD}^{+}{ }^{+} \mathrm{CD}^{-} 3^{-}$newly formed B-cells were not changed among tested cell types (Figure $6 \mathrm{~b}$ and $\mathrm{c}$ ). Data from the cell population identification with cocultures were averaged and summarized in Supplementary Table S3.

To examine whether the B-cell populations derived from OBN4 cocultures are functional, we finally tested the activation of B-cells by stimulation with a combination of LPS, IL-4 and CD40L. After $24 \mathrm{~h}$ of stimulation, the activation of B-cells was analyzed by counting the number of colonized cells and measuring the gene expression of B-cell activation markers using real-time PCR. As shown in Figure $6 \mathrm{~d}$ and Supplementary Figure S2, OBN4-derived B220 ${ }^{+}$B-cells 
a

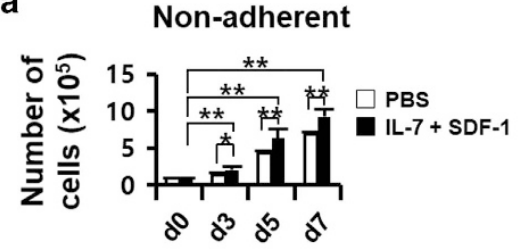

c

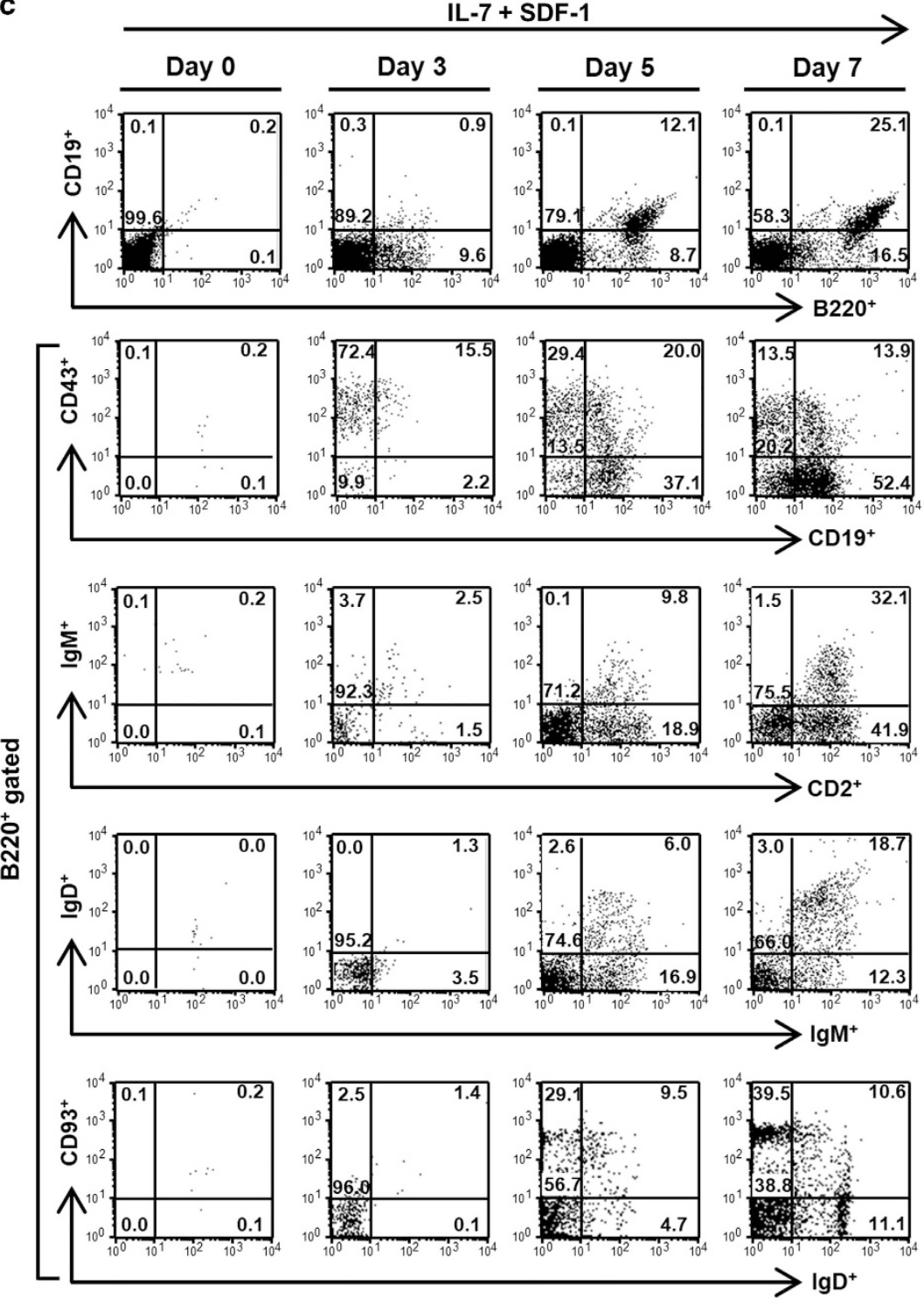

d

$\square$ PBS $\square \mathrm{IL}-7$ + SDF-1

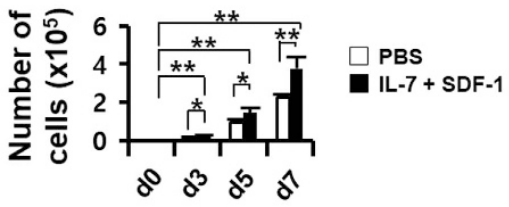

B220+CD19-CD43 ${ }^{+}$

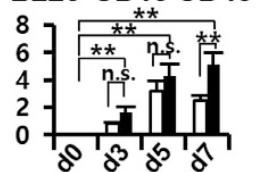

$\mathrm{B}^{2} 20^{+} \mathrm{CD} 19^{+} \mathrm{CD} 43^{+}$

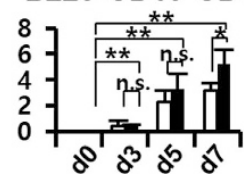

B220+CD19+CD43-

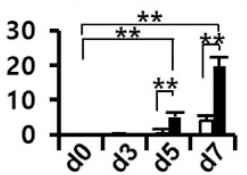

$\mathrm{B220}^{+} \operatorname{lgM}-\mathrm{CD}^{+}$

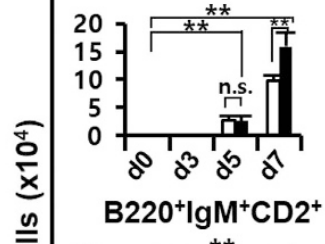

$\mathrm{B}^{2} 20^{+} \mathrm{IgM} \mathrm{M}^{+} \mathrm{CD} 2^{+}$

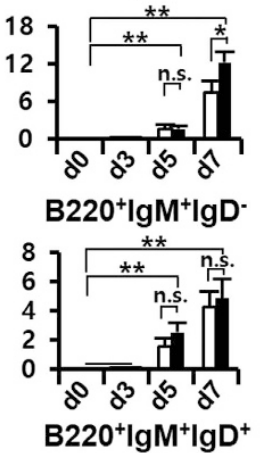

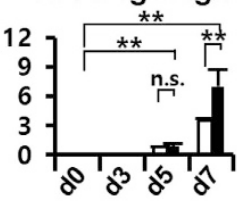

$\mathrm{B}^{2} 20^{+} \lg \mathrm{D}^{+} \mathrm{CD} 93^{-}$

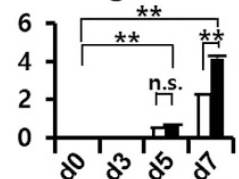

Figure 5 In vitro B lymphopoiesis of $\mathrm{Lin}^{-} \mathrm{Sca}-1^{+} \mathrm{c}-\mathrm{Kit}{ }^{+} \mathrm{HSPCs}$ in coculture with OBN4 cells. (a) The increase in the number of nonadherent cells under coculture. LSK cells $\left(10^{5}\right.$ cells per well of a 6 -well plate) isolated as shown in Figure 4 were cocultured on monolayers of the OBN4 cells $\left(6 \times 10^{4}\right.$ cells per well) in the presence or absence of IL-7 $\left(100 \mathrm{ng} \mathrm{ml}^{-1}\right)$ and SDF-1 (100 ng ml $\left.\mathrm{I}^{-1}\right)$ for $7 \mathrm{~d}$. Black box, cytokine treatment. Open box, phosphate-buffered saline (PBS, non-cytokine treatment). (b) The increase in the number of B220 ${ }^{+}$cells under coculture. (c) In vitro B lymphopoiesis of HSPCs in coculture with OBN4 cells in the presence of IL-7 and SDF-1. The development of B-lineage cells was analyzed via flow cytometry with antibodies against B220, CD2, CD19, CD43, CD93, IgM and IgD during coculture with OBN4 for $7 \mathrm{~d}$. The presented numbers indicate the percentage of each cell population. (d) The average numbers of B-lineage cells produced during coculture with OBN4 cells were summarized. NS, not significant. ${ }^{*} P<0.05$. ${ }^{* *} P<0.01$. 
exhibited relatively higher B-cell proliferation and expression of B-cell activation markers than primary osteoblasts, $\mathrm{OBN} 4^{\mathrm{MT}}$ and OP9 cells, although the activation values were lower than those of the purified $\mathrm{B} 220^{+}$splenocytes. In summary, these results indicate that OBN4 cells are more efficient than primary

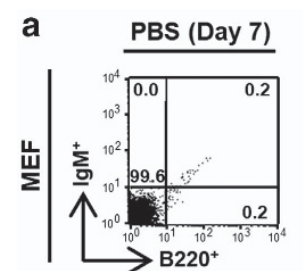

b

IL-7 + SDF-1 (Day 7)
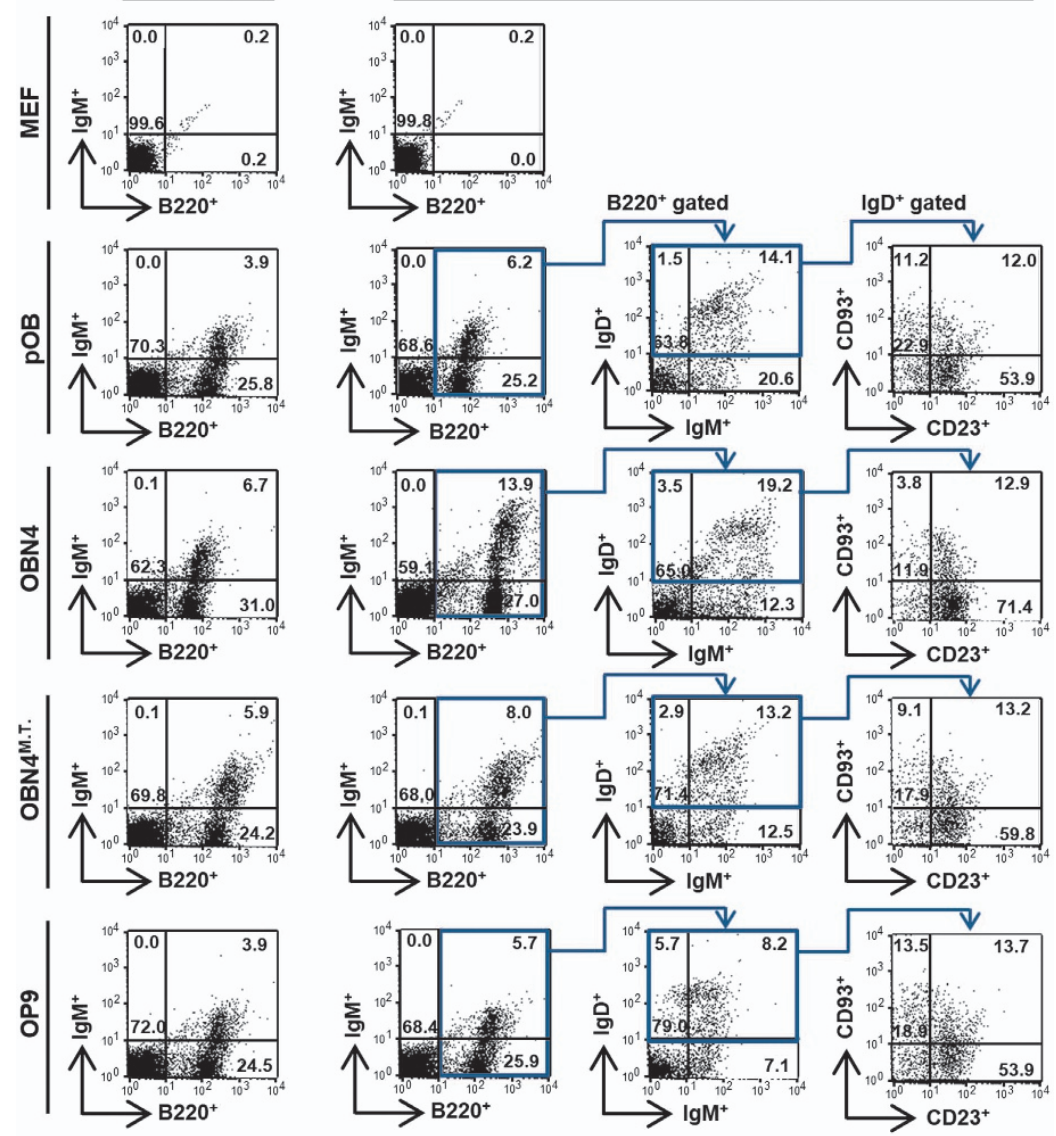

C

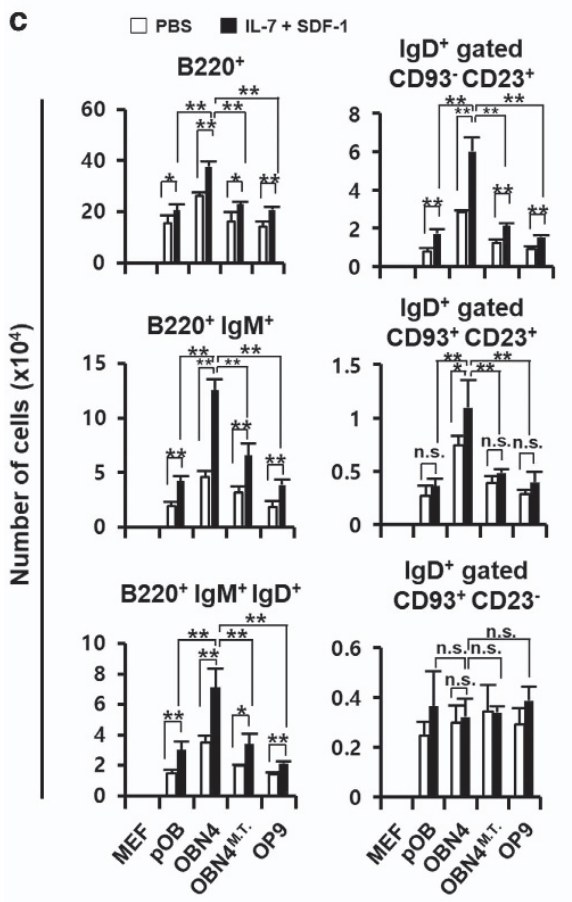

d $\square$ PBS $\quad \square \mathrm{LL}-7+\mathrm{SDF}-1$

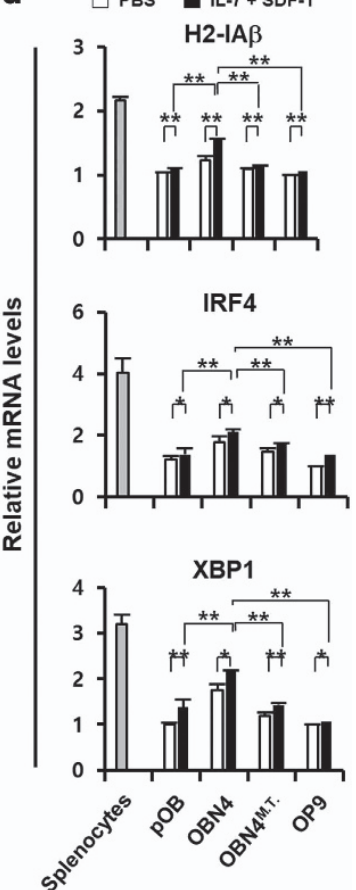


osteoblasts or OP9 stromal cells in inducing in vitro B lymphopoiesis in $\mathrm{Lin}^{-} \mathrm{Sca}-1^{+} \mathrm{c}-\mathrm{Kit}^{+}$HSPCs.

\section{DISCUSSION}

B lymphopoiesis from HSCs in the bone marrow is a highly ordered multistep process that depends on signals generated by the hematopoietic niche. ${ }^{8}$ The external cytokine signals produced by the hematopoietic niche play a crucial role in regulating $\mathrm{B}$ lymphopoiesis in bone marrow. In particular, the roles of several cytokines (such as SCF, SDF-1, Flt3L and IL-7) that stimulate HSC differentiation into the B-cell population in bone marrow have been demonstrated. ${ }^{14,30-32}$ The binding of cytokines to their receptors on HSCs can subsequently stimulate transcriptional networks in HSCs to induce B lymphopoiesis. Thus, the process of B-cell differentiation is regulated by multiple networks of transcription factors, such as Ikaros, E2A, early B-cell factor and paired box protein five, induced by external signals derived from the hematopoietic niche. ${ }^{6-8,15}$ Furthermore, studies have reported that the reduced expression of adhesion molecules, such as vascular cell adhesion molecule-1 and integrins, on bone marrow stromal cells correlates with a reduced capacity to support in vitro B lymphopoiesis. ${ }^{33-36}$ Therefore, the specific cell-cell interaction between HSCs and their hematopoietic niche is required for efficient in vitro B lymphopoiesis. However, despite a great deal of progress in the past decade, the ability to efficiently induce in vitro B lymphopoiesis remains in a primitive stage, and many of the signaling pathways of cytokines and adhesion molecules that affect B lymphopoiesis have yet to be discovered.

The main cellular components of bone are osteoblast lineage cells that work in groups to secrete and mineralize new bone matrix for bone formation. ${ }^{37}$ Osteoblasts, which are primarily located in the hematopoietic niche, support the growth of hematopoietic progenitor cells and produce cytokines that regulate hematopoiesis. ${ }^{38}$ Thus, osteoblasts function as a key component of the hematopoietic niche and provide essential signals and play supportive roles in HSC self-renewal and differentiation. ${ }^{39-41}$ Moreover, the function of osteoblasts is directly linked to the integrity of the humoral immune system through the induction of B lymphopoiesis. ${ }^{42,43}$ Indeed, conditional ablation of osteoblast cells or their functions in bone marrow results in a rapid reduction of B-cell populations, preceding the loss of HSCs in vivo. ${ }^{39,41}$ Furthermore, studies have reported that primary osteoblasts are capable of supporting all stages of B-cell differentiation from HSCs in vitro. ${ }^{14,15}$ In particular, production of $\operatorname{IgM}^{+}$B lymphocytes from HSCs is induced upon coculture with primary osteoblasts, suggesting that osteoblasts support the differentiation of immature/naive B-cells in vitro. ${ }^{14,15}$ However, the question remains of whether osteoblasts alone support in vitro B lymphopoiesis. Studies have reported that stromal cells, such as OP9 and MS-5, are able to support in vitro B lymphopoiesis. ${ }^{9-11}$ Osteoblasts are derived from multipotential mesenchymal stem cells that also give rise to a variety of mesenchymal lineage cells, such as fibroblasts, chondrocytes, myoblasts, adipocytes and stromal cells. ${ }^{42,43}$ Thus, we cannot clearly exclude the possibility that in vitro $\mathrm{B}$ lymphopoiesis is induced via contributions from other cell types of the mesenchymal lineage contaminating the batch preparation of primary osteoblasts. In this study, we therefore established a stable osteoblastic cell line (OBN4) that functions as an osteoblast-based artificial niche to induce the production of $\operatorname{IgM}^{+}$B lymphocytes in vitro from HSPCs (Figure 6). The results of this work suggest that osteoblasts play the major necessary and sufficient roles in supporting in vitro B lymphopoiesis.

The efficiency of $\operatorname{IgM}^{+}$B-cell production in vitro by primary osteoblasts per se is lower compared with the potential of the hematopoietic niche in vivo, indicating that additional factors, such as cytokines, growth factors or adhesion molecules produced by the OBN or other cell types of the hematopoietic niche, are required for the efficient induction of in vitro B lymphopoiesis. ${ }^{14,15,38}$ Indeed, studies have reported that the process of B lymphopoiesis in vivo is critically dependent upon the actions of various cytokines, such as SDF-1 and IL-7, which are produced from multiple cell types in the hematopoietic niche. ${ }^{44}$ Interestingly, we observed that PTH-stimulated OBN4 cells without IL-7 and SDF-1 supplementation were not sufficient to enhance efficient $\operatorname{IgM}^{+}$B-cell production in vitro (Figures 5 and 6), although studies have reported that PTH induces the production of both IL-7 and SDF-1 in

Figure 6 OBN4 cells efficiently support in vitro B lymphopoiesis. (a) Comparison of B-cell production from HSPCs in coculture with different cell types in the absence of cytokine supplementation. Flow cytometry analysis of in vitro B lymphopoiesis in coculture. The nonadherent cells derived from coculture in the absence of cytokine supplementation (PBS) for $7 \mathrm{~d}$ were analyzed via flow cytometry with antiB220 and anti-lgM antibodies. The presented numbers indicate the percentage of each cell population. MEFs were used as a negative control. pOB, primary osteoblast. OBN4 ${ }^{\mathrm{MT}}$, OBN4 cells placed in cell cycle arrest by mitomycin $\left(1.5 \mu \mathrm{ml}^{-1}\right)$ treatment. (b) Comparison of B-cell production from HSPCs with coculture of different cell types in the presence of IL-7 and SDF-1. The non-adherent cells were analyzed by flow cytometry with anti-B220 and anti-lgM antibodies. The B220+ gated cells (bolded box) were further analyzed using antiIgM and anti-IgD antibodies (second panel). The IgD+ gated cells (bolded box) were analyzed using anti-CD93 and anti-CD23 antibodies (third panel). (c) The average numbers of B-cell production from HSPCs with coculture of different cell types in the absence or presence of IL-7 and SDF-1 were summarized. Black box, cytokine treatment. Open box, phosphate-buffered saline (PBS, non-cytokine treatment). NS, not significant. ${ }^{*} P<0.05$. ${ }^{* *} P<0.01$. (d) Comparison of activation marker expression in $\mathrm{B}^{2} 2 \mathrm{O}^{+}$cells produced from the coculture. The $\mathrm{B}_{22}{ }^{+}$cells produced from the coculture were stimulated for $24 \mathrm{~h}$ with LPS $\left(1 \mu \mathrm{g} \mathrm{ml}^{-1}\right)$, IL-4 $\left(10 \mathrm{ng} \mathrm{ml}^{-1}\right)$ and CD40L $\left(100 \mathrm{ng} \mathrm{ml}{ }^{-1}\right)$ treatment. The relative expression levels of H2-IA $\beta$, IRF4 and XBP1 were analyzed via real-time PCR analysis. The B220 ${ }^{+}$splenocytes were used as a positive control (grey box). 
osteoblasts. ${ }^{14,40}$ When the coculture plates were exogenously supplemented with the combination of IL-7 and SDF-1, the production of $\mathrm{IgM}^{+} \mathrm{B}$-cells was more efficiently induced by OBN4 cells (Figures 5 and 6). Therefore, sufficient expression of IL-7 and SDF-1 in OBN4 cells may be required for the efficient production of $\operatorname{IgM}^{+}$B lymphocytes during the process of in vitro B lymphopoiesis. However, previous studies demonstrated that IL-7 and SDF-1 are key players in the early stage of B-cell development and that the surface expression of IL-7 receptor (IL-7R) or CXCR4 is limited to early B lineage cells. ${ }^{45,46}$ Thus, in our current study, the question remains how IL-7 and SDF-1 supplementation can induce the production of $\operatorname{IgM}^{+}$B-cells during in vitro B lymphopoiesis. One possible explanation would be the indirect effects of exogenous IL-7 and SDF-1 supplementation on other cell types derived from HSPCs with OBN4 coculture or on OBN4 cells themselves. The supplementation of IL-7 and SDF-1 may induce signaling activation in other cell types produced by coculture or in OBN4 cells themselves that possibly secrete or express B-cell maturation cytokines such as IL-4 or BAFF or cell adhesion molecules such as VCAM-1 to stimulate in vitro B lymphopoiesis. In addition, there is increasing evidence of the functional role of complex cytokine signaling networks, such as the Wnt, CD40, CD38, IL-27, IFN and RANKL networks, in B lymphopoiesis in vivo. ${ }^{13,47-52}$ Thus, efficient in vitro B lymphopoiesis may require complex cellular and molecular networks between HSCs and the OBN.

In this study, we developed a stable osteoblastic cell line, designated OBN4, which functions as an osteoblast-based artificial niche for in vitro B lymphopoiesis. The stable clone OBN4 exhibited higher expression of osteoblast markers than the other stable clones. We demonstrated that in vitro B lymphopoiesis was more efficiently induced by the OBN4 clone than by primary osteoblasts or OP9 stromal cells. Overall, the results of this study indicate that the stable clone OBN4 functions as an osteoblast-based artificial niche to induce in vitro $\mathrm{B}$ lymphopoiesis of $\mathrm{Lin}^{-} \mathrm{Sca}^{+}{ }^{+} \mathrm{c}-\mathrm{Kit}^{+} \mathrm{HSPCs}$. Therefore, these findings raise the possibility of developing a technique for highly efficient in vitro B-cell production in the future to provide protective immunity against dangerous infections or cancers.

\section{CONFLICT OF INTEREST}

The authors declare no conflict of interest.

\section{ACKNOWLEDGEMENTS}

This research was supported by a Ministry of the National Defense Foundation Grant (ADD: 08-10-02, 14-01-06-06) and the Basic Science Research Program through the National Research Foundation of Korea (NRF) and was funded by the Ministry of Education (NRF-2017R1A2B4007327) and by the research fund of Chungnam National University.

\section{PUBLISHER'S NOTE}

Springer Nature remains neutral with regard to jurisdictional claims in published maps and institutional affiliations.
1 Dzierzak E, Speck NA. Of lineage and legacy: the development of mammalian hematopoietic stem cells. Nat Immunol 2008; 9: 129-136.

2 Calvi LM, Link DC. Cellular complexity of the bone marrow hematopoietic stem cell niche. Calcif Tissue Int 2013; 94: 112-124.

3 Yin T, Li L. The stem cell niches in bone. J Clin Invest 2006; 116: 1195-1201.

4 Schofield R. The relationship between the spleen colony-forming cell and the haemopoietic stem cell. Blood Cells 1978; 4: 7-25.

5 Wilson A, Trumpp A. Bone-marrow haematopoietic-stem-cell niches. Nat Rev Immunol 2006; 6: 93-106.

6 Hagman J, Lukin K. Transcription factors drive B cell development. Curr Opin Immunol 2006; 18: 127-134.

7 Nutt SL, Kee BL. The transcriptional regulation of B cell lineage commitment. Immunity 2007; 26: 715-725.

8 Singh $\mathrm{H}$, Medina KL, Pongubala JM. Contingent gene regulatory networks and B cell fate specification. Proc Natl Acad Sci USA 2005; 102 : 4949-4953.

9 Tokoyoda K, Egawa T, Sugiyama T, Choi BI, Nagasawa T. Cellular niches controlling $\mathrm{B}$ lymphocyte behavior within bone marrow during development. Immunity 2004; 20: 707-718.

10 Lagergren A, Mansson R, Zetterblad J, Smith E, Basta B, Bryder D et al. The $\mathrm{Cxcl12}$, periostin, and $\mathrm{Ccl}$ 9 genes are direct targets for early B-cell factor in OP-9 stroma cells. J Biol Chem 2007; 282: 14454-14462.

11 Taguchi T, Takenouchi H, Shiozawa Y, Matsui J, Kitamura N, Miyagawa Y et al. Interleukin-7 contributes to human pro-B-cell development in a mouse stromal cell-dependent culture system. Exp Hematol 2007; 35: 1398-1407.

12 Carpenter L, Malladi R, Yang CT, French A, Pilkington KJ, Forsey RW et al. Human induced pluripotent stem cells are capable of B-cell lymphopoiesis. Blood 2011; 117: 4008-4011.

13 Cho SK, Webber TD, Carlyle JR, Nakano T, Lewis SM, Zuniga-Pflucker JC. Functional characterization of $B$ lymphocytes generated in vitro from embryonic stem cells. Proc Natl Acad Sci USA 1999; 96: 9797-9802.

14 Zhu J, Garrett R, Jung Y, Zhang Y, Kim N, Wang J et al. Osteoblasts support B-lymphocyte commitment and differentiation from hematopoietic stem cells. Blood 2007; 109: 3706-3712.

15 Wu JY, Purton LE, Rodda SJ, Chen M, Weinstein LS, McMahon AP et al. Osteoblastic regulation of $\mathrm{B}$ lymphopoiesis is mediated by Gs\{alpha\}dependent signaling pathways. Proc Natl Acad Sci USA 2008; 105: 16976-16981.

16 Park ES, Choi S, Kim JM, Jeong Y, Choe J, Park CS et al. Early embryonic lethality caused by targeted disruption of the TRAF-interacting protein (TRIP) gene. Biochem Biophys Res Commun 2007; 363: 971-977.

17 Yu J, Choi S, Park ES, Shin B, Lee SH, Takami M et al. D-chiro-inositol negatively regulates the formation of multinucleated osteoclasts by downregulating NFATc1. J Clin Immunol 2012; 32: 1360-1371.

18 Park ES, Choi S, Shin B, Yu J, Hwang JM, Yun H et al. Tumor necrosis factor (TNF) receptor-associated factor (TRAF)-interacting protein (TRIP) negatively regulates the TRAF2 ubiquitin-dependent pathway by suppressing the TRAF2-sphingosine 1-phosphate (S1P) interaction. J Biol Chem 2015; 290: 9660-9673.

19 Shin B, Yu J, Park ES, Choi S, Hwang JM, Yun H et al. Secretion of a truncated osteopetrosis-associated transmembrane protein 1 (OSTM1) mutant inhibits osteoclastogenesis through down-regulation of the $B$ lymphocyte-induced maturation protein 1 (BLIMP1)-nuclear factor of activated $\mathrm{T}$ cells $\mathrm{cl}$ (NFATc1) axis. J Biol Chem 2014; 289 . 35868-35881.

20 Park ES, Kim J, Ha TU, Choi JS, Soo Hong K, Rho J. TDAG51 deficiency promotes oxidative stress-induced apoptosis through the generation of reactive oxygen species in mouse embryonic fibroblasts. Exp Mol Med 2013; 45: e35.

21 Aguila JR, Liao W, Yang J, Avila C, Hagag N, Senzel L et al. SALL4 is a robust stimulator for the expansion of hematopoietic stem cells. Blood 2011; 118: 576-585.

22 Himburg HA, Muramoto GG, Daher P, Meadows SK, Russell JL, Doan P et al. Pleiotrophin regulates the expansion and regeneration of hematopoietic stem cells. Nat Med 2010; 16: 475-482.

23 Lui WC, Chan YF, Chan LC, Ng RK. Cytokine combinations on the potential for ex vivo expansion of murine hematopoietic stem cells. Cytokine 2014; 68: 127-132.

24 Granato A, Hayashi EA, Baptista BJ, Bellio M, Nobrega A. IL-4 regulates Bim expression and promotes $B$ cell maturation in synergy with BAFF 
conferring resistance to cell death at negative selection checkpoints. $\mathrm{J}$ Immunol 2014; 192: 5761-5775.

25 Iwasaki H, Akashi K. Hematopoietic developmental pathways: on cellular basis. Oncogene 2007; 26: 6687-6696.

26 Mayle A, Luo M, Jeong M, Goodell MA. Flow cytometry analysis of murine hematopoietic stem cells. Cytometry A 2013; 83: 27-37.

27 Allman D, Pillai S. Peripheral B cell subsets. Curr Opin Immunol 2008; 20: 149-157.

28 Rolink AG, Andersson J, Melchers F. Molecular mechanisms guiding late stages of B-cell development. Immunol Rev 2004; 197: 41-50.

29 Thomas MD, Srivastava B, Allman D. Regulation of peripheral B cell maturation. Cell Immunol 2006; 239: 92-102.

$30 \mathrm{Ma}$ Q, Jones D, Springer TA. The chemokine receptor CXCR4 is required for the retention of $B$ lineage and granulocytic precursors within the bone marrow microenvironment. Immunity 1999; 10: 463-471.

31 Nagasawa T, Hirota S, Tachibana K, Takakura N, Nishikawa S, Kitamura Y et al. Defects of B-cell lymphopoiesis and bone-marrow myelopoiesis in mice lacking the CXC chemokine PBSF/SDF-1. Nature 1996; 382: 635-638.

32 von Freeden-Jeffry $U$, Vieira $P$, Lucian LA, McNeil T, Burdach SE, Murray R. Lymphopenia in interleukin (IL)-7 gene-deleted mice identifies IL-7 as a nonredundant cytokine. J Exp Med 1995; 181: 1519-1526.

33 Dittel BN, Le Bien TW. Reduced expression of vascular cell adhesion molecule-1 on bone marrow stromal cells isolated from marrow transplant recipients correlates with a reduced capacity to support human B lymphopoiesis in vitro. Blood 1995; 86: 2833-2841.

34 Funk PE, Stephan RP, Witte PL. Vascular cell adhesion molecule 1-positive reticular cells express interleukin-7 and stem cell factor in the bone marrow. Blood 1995; 86: 2661-2671.

35 Glodek AM, Honczarenko M, Le Y, Campbell JJ, Silberstein LE. Sustained activation of cell adhesion is a differentially regulated process in B lymphopoiesis. J Exp Med 2003; 197: 461-473.

36 Schaumann DH, Tuischer J, Ebell W, Manz RA, Lauster R. VCAM-1-positive stromal cells from human bone marrow producing cytokines for B lineage progenitors and for plasma cells: SDF-1, flt3L, and BAFF. Mol Immunol 2007; 44: 1606-1612.

37 Arnett T. Regulation of bone cell function by acid-base balance. Proc Nutr Soc 2003; 62: 511-520.

38 Horowitz MC, Bothwell AL, Hesslein DG, Pflugh DL, Schatz DG. B cells and osteoblast and osteoclast development. Immunol $\operatorname{Rev} 2005$; 208: 141-153.

39 Calvi LM. Osteoblastic activation in the hematopoietic stem cell niche. Ann N Y Acad Sci 2006; 1068: 477-488.

40 Calvi LM, Adams GB, Weibrecht KW, Weber JM, Olson DP, Knight MC et al. Osteoblastic cells regulate the haematopoietic stem cell niche. Nature 2003; 425: 841-846.

41 Visnjic D, Kalajzic Z, Rowe DW, Katavic V, Lorenzo J, Aguila HL. Hematopoiesis is severely altered in mice with an induced osteoblast deficiency. Blood 2004; 103: 3258-3264.
42 Taichman RS, Emerson SG. The role of osteoblasts in the hematopoietic microenvironment. Stem Cells 1998; 16: 7-15.

43 Taichman RS, Reilly MJ, Emerson SG. The hematopoietic microenvironment: osteoblasts and the hematopoietic microenvironment. Hematology 2000; 4: 421-426.

44 Panaroni C, Wu JY. Interactions between B lymphocytes and the osteoblast lineage in bone marrow. Calcif Tissue Int 2013; 93: 261-268.

45 Clark MR, Mandal M, Ochiai K, Singh H. Orchestrating B cell lymphopoiesis through interplay of IL-7 receptor and pre-B cell receptor signalling. Nat Rev Immunol 2014; 14: 69-80.

46 Egawa T, Kawabata K, Kawamoto H, Amada K, Okamoto R, Fujii N et al. The earliest stages of $\mathrm{B}$ cell development require a chemokine stromal cellderived factor/pre-B cell growth-stimulating factor. Immunity 2001; 15: 323-334.

47 Gongora R, Stephan RP, Schreiber RD, Cooper MD. Stat-1 is not essential for inhibition of B lymphopoiesis by type I IFNs. J Immunol 2000; 165: 2362-2366.

48 Kong YY, Feige U, Sarosi I, Bolon B, Tafuri A, Morony S et al. Activated $T$ cells regulate bone loss and joint destruction in adjuvant arthritis through osteoprotegerin ligand. Nature 1999; 402: 304-309.

49 Liu XQ, Hart DN, MacPherson GG, Good MF, Wykes MN. Soluble CD38 significantly prolongs the lifespan of memory B-cell responses. Immunology 2008; 125: 14-20.

50 Merluzzi S, Moretti M, Altamura S, Zwollo P, Sigvardsson M, Vitale G et al. CD40 stimulation induces Pax5/BSAP and EBF activation through a APE/ Ref-1-dependent redox mechanism. J Biol Chem 2004; 279: 1777-1786.

51 Seita J, Askawa M, Ooehara J, Takayanagi S, Morita Y, Watanabe N et al. Interleukin-27 directly induces differentiation in hematopoietic stem cells. Blood 2008; 111: 1903-1912.

52 Staal FJ, Sen JM. The canonical Wnt signaling pathway plays an important role in lymphopoiesis and hematopoiesis. Eur J Immunol 2008; 38: 1788-1794.

(c) (1) (E) $€$ This work is licensed under a Creative Commons Attribution-NonCommercial-NoDerivs $\quad 4.0$

International License. The images or other third party material in this article are included in the article's Creative Commons license, unless indicated otherwise in the credit line; if the material is not included under the Creative Commons license, users will need to obtain permission from the license holder to reproduce the material. To view a copy of this license, visit http://creativecommons.org/licenses/by-nc-nd/4.0/

(C) The Author(s) 2017

Supplementary Information accompanies the paper on Experimental \& Molecular Medicine website (http://www.nature.com/emm) 